\title{
A TERÜLETI TERVEZÉS LEGÚJABB KÖRNYEZETÉRTÉKELÉSI METÓDUSA - A STRATÉGIAI KÖRNYEZETI VIZSGÁLAT INTEGRÁCIÓJA A DÖNTÉSHOZÁSBA
}

\author{
(The Latest Environmental Assessment Method in Land-use \\ Planning - Strategic Environmental Assessment [SEA] \\ Integration in Decision-making)
}

\section{VARJÚ VIKTOR}

\begin{abstract}
Kulcsszavak:
stratégiai környezeti vizsgálat (SKV) környezeti hatásvizsgálat (KHV) település-és területfejlesztés környezetpolitika

A fenntartható fejlödés fogalma manapság rendkivül népszerü, és gyakorlati megnyilvánulása is rendkivül széles körü. A fenntarthatóság és környezeti érdekek számbavételének legnagyobb jelentösége éppen a területi tervezésben van. A tamulmány a területi tervezés egy ủj környezeti értékelési metódusát, a stratégiai környezeti vizsgálatot (SKV) mutatja be. Jelen tanulmányban a környezeti értékelésnek azonban nem a módszertana, hanem a tervezésben és a döntéshozásban betöltött szerepe kerïl ismertetésre. Az integráció elméleti kereteinek bemutatása mellett - részben a hazai eddigi gyakorlatot citálva - a tervekre vonatkozó környezeti vizsgálat kívánatos és ideális helyét határozza meg a szerzö. A döntéshozói szinteken megmutatkozó gyengeségek bemutatása elsỏsorban a figyelemfelhivást szolgálja annak érdekében, hogy a stratégiai környezeti vizsgálat valóban a neki szánt, iteratív funkcióját töltse be, nem pedig egy újabb kötelezó költségvetési tételként jelenjen meg.
\end{abstract}

\section{Bevezetés}

A társadalom és környezete között fennálló kölcsönhatást már sokszor és sokan vizsgálták, értelmezték, modellálták. Az embert körülvevő természeti környezetet, annak erőforrásait évezredek óta használja az emberiség. Éppen ezért annak (fel)értékelése is újra és újra felbukkan a különböző szakterületek irodalmaiban. A természeti erőforrások számbavétele és használata kezdetekben az alapvető szükségletek kielégítésében merült ki. A társadalmi, kulturális fejlődéssel párhuzamosan aztán egyre nagyobb mértékben használtuk környezetünk eröforrásait, mely a ma számos helyen hangoztatott túlhasználathoz vezetett.

Ahhoz, hogy a minket körülvevő környezet rendelkezésre álló erőforrásainak kimerítését megakadályozzuk - bár a fejlődő tudomány, valamint az elérhető legjobb technikák alkalmazása az erőforrások hatékony használata mellett azok folyamatos bővülését is eredményezi -, szükség van az emberi tevékenységek elözetes értéke- 
Varjú Viktor : A területi tervezés legújabb környezetértékelési metódusa - A stratégiai környezeti

vizsgálat integrációja a döntéshozásba. - Tér és Társadalom 23. évf. 2009/1. 55-65. p.

56 Varjú Viktor

TÉT XXIII. évf. 2009

lésére, a várható hatások elözetes becslésére. Ilyen környezeti vizsgálati eljárásokat az 1960-as évek elejétöl kezdtek használni (Szilvácsku 2003). A figyelem középpontja először a projekt/beruházás szintü környezeti hatásvizsgálatokra (KHV) terelődött, ahol a földrajzi környezetbe történő közvetlen emberi beavatkozások hatásait becsülték/becsülik meg. Így az 1970-es évektől egyre nagyobb mértékben kerültek be a környezeti szempontok a döntéshozatali folyamatokba.

A KHV a beruházások, konkrét projektek hatásainak elemzésére irányul tehát. A folyamatos környezeti terheléssel együtt megfogalmazódott azonban egy olyan eljárás kifejlesztésének igénye is, amely már korábbi fázisban, szakpolitikák, tervek és programok kialakításakor elötérbe helyezi a környezeti szempontokat. Ez az ún. stratégiai környezeti vizsgálat (SKV), melyet először az 1980-as évek végén Hollandiában, majd az 1990-es évektöl Új-Zélandon, Kanadában, Nagy-Britanniában, az USA-ban, majd fokozatosan a többi nyugat-európai országban is elkezdtek alkalmazni (Tombácz et al 2003).

A magyarországi terület- és településfejlesztés számára a lehetöséget (vagy kényszert?) azonban csak az EU 2001/42/EK az egyes tervek és programok környezetre gyakorolt hatásainak vizsgálatáról címü irányelve hozta meg, amely arra kötelezte a tagországokat, hogy 2004. július 21 -ét követően jogszabályban rögzítsék, majd alkalmazzák is a területi tervezésben az elözetes környezeti vizsgálatot. Ennek a követelménynek Magyarország végül a 2/2005. (I.11.) kormányrendeletben tett eleget.

\section{A stratégiai környezeti vizsgálat (SKV)}

A stratégiai környezeti vizsgálat (SKV) célja tehát, hogy megvédje az emberi tevékenységtől az embert körülvevő földrajzi környezetet, benne magát az embert is. Ellentétben a beruházásokhoz kapcsolódó KHV-val, az SKV már a tervezés fázisában hivatott a környezeti szempontokat érvényesiteni. Ezért környezeti vizsgálatot kell végezni olyan tervek és programok készítésekor, amelyek valószínủleg jelentös hatással lesznek a környezetre (Ferencsik 2004). Ez az intézkedés kiterjed a nemzeti, regionális vagy helyi szintủ programokra és tervekre, fejlesztési dokumentumokra (pl. NSRK, ROP, megyei és település-, területrendezési tervek stb.).

A stratégiai környezeti vizsgálat a döntéshozatali folyamat magasabb szintjeinek környezeti célú integráltságát biztosító döntés-előkészítő eljárás. Ennek segítségével a projektszinten túlmutatóan - az egyes politikai irányelvek, koncepciók, programok környezettudatos és fenntarthatósági szempontokat hozhatnak szinkronba. Jellemzően nem elsősorban egyfajta hatásbecslésröl van szó tehát, hanem a környezeti és fenntarthatósági szempontoknak a programozás korai szakaszában történő érvényesítéséröl, illetőleg a projektek kumulatív környezeti hatásvizsgálatának fontos eszközéről (Péti 2005). 
Varjú Viktor : A területi tervezés legújabb környezetértékelési metódusa - A stratégiai környezeti vizsgálat integrációja a döntéshozásba. - Tér és Társadalom 23. évf. 2009/1. 55-65. p.

TÉT XXIII. évf. 2009 『 1

A területi tervezés ...

Az SKV egyik fö jellegzetessége, hogy együtt készül a tervvel, így menet közben jutnak érvényre a környezeti érdekek. A vizsgálatnak minden esetben környezetvédelmi szempontból is elfogadható, kompromisszumokat tartalmazó programot kell eredményeznie. A vizsgálat szorosan kapcsolódik a fenntarthatóság eszméjéhez, mely segíti tehát az ilyen irányú elmozdulást.

\section{Az SKV jelentösége a település- és területfejlesztésben}

Az 1980-as évek végén az egyre erősödő környezetvédelmi, tudományos jellegü megfontolások mellett egyre erösebb szerephez jutottak a környezetvédelmi társadalmi mozgalmak, melyek nemcsak az államszocialista rendszert támadták, hanem az ökológiai szempontok közgondolkodásban történő nagyobb szerepre jutása mellett is kardoskodtak. Bár a rendszerváltozást követően javultak a környezetvédelem szervezeti, intézményesült, valamint civil keretfeltételei és rendszerei, a kilencvenes években a környezetvédelem és problematikája egyértelmủen visszaszorult (Szirmai 1999).

Az ezredfordulótól fokozatosan megerösödő európaizáció, - melynek sajátossága, hogy nem csupán azokon a területeken következik be, ahol az alkalmazkodás lényegében kötelezö, hanem azon területeken is, ahol nincs ilyen kényszer (Pálné 2005, 11) - azonban újabb kihívást jelentett nemcsak a fejlesztések, az egyre szükülő erőforrások allokálásának és szerkezeti átalakításának terén, hanem a földrajzi környezet megóvásával kapcsolatban is. A különbözö érvényességủ és szintü, a környezet védelmét szolgáló intézkedések, normák, értékelések (környezeti hatásvizsgálat, környezeti felülvizsgálat, stratégiai környezeti vizsgálat, EMAS rendszer, ISO 14001, EU Környezetvédelmi Akcióprogramok, I. és II. Nemzeti Környezetvédelmi Program stb.) mind a földrajzi környezetünket hivatottak megvédeni saját tevékenységünk következményeitől. Ezek a rendszerek és keretelvek azonban egyre inkább tudatosítják, hogy nem elég szabályozni, hanem fel kell hívni a figyelmet a kormányzás problémáira is a környezetpolitikában, és nemcsak a beruházási, végrehajtási szintre kell fókuszálnunk, hanem már a tervezés során tudatosítani kell a környezeti szempontok érvényre juttatásának szükségszerüségét.

A stratégiai környezeti vizsgálat folyamatának azonban nemcsak a nemzeti léptékü, országos szintủ tervezésben van jelentősége (hiszen a már említett irányelvnek megfelelöen a Strukturális Alapokhoz kötödö tervezés dokumentumaihoz [pl. II. Nemzeti Fejlesztési Terv, regionális operatív programok, ágazati operatív programok] már megtörténtek a stratégiai környezeti vizsgálatok). Mint már említésre került, a környezeti értékelésről szóló jogszabályok (1995. évi LIII. tv., 2/2005 (I.11.) Kormányrendelet stb.) meghatározzák azon programok és tervek körét, melyekre elözetes környezeti értékelést kell végezni. Ide tartoznak a megyei és települési rendezési tervek, a település egészére készülő településszerkezeti terv, helyi építési szabályzat és szabályozási terv, valamint a településfejlesztési koncepciók is. Mivel azonban az SKV intézménye frissnek mondható, hiszen az erre vonatkozó törvény csak 2005. év elején jelent meg, ezért különösen fontos az első idöszak a tervezési és értékelési 
Varjú Viktor : A területi tervezés legújabb környezetértékelési metódusa - A stratégiai környezeti

vizsgálat integrációja a döntéshozásba. - Tér és Társadalom 23. évf. 2009/1. 55-65. p.

folyamatban. Az országos és regionális szintü tervezési dokumentumoknak kiemelt szerepet kell kapniuk nemcsak a tervezés, hanem a környezeti értékelés folyamatában is. Éppen itt ragadható meg tehát az ezen programok tervezését, koordinálását és értékelését végzők felelössége. Az iterativ, reflexív folyamatnak meg kell jelennie a területi, illetve a települési szintü fejlesztési koncepciók felülvizsgálati folyamatában, annak érdekében, hogy a környezetvédelmi érdekek érvényesüljenek.

\section{A környezetpolitika integrációja a területfejlesztés folyamatába}

A korábban már említett értékelési metódusokon kívül még számtalan hatásbecsléssel találkozhatunk, fỏként az egyes szakmákhoz kötődően, amelyek az emberi tevékenység hatásait próbálják megbecsülni, és ezáltal befolyással lenni a döntéshozókra egy fenntarthatóbb társadalmi berendezkedés felé. Ilyen a közgazdaságtanban a költség-haszon (cost-benefit) elemzés, a költség-hatékonyság (costeffectiveness), a fiskális hatás értékelés (fiscal impact assessment), a logikai keret analizis (logical framework analyses), vagy éppen az input-output vizsgálat. Ezek többnyire gazdasági oldalról közelítenek a döntéshozás folyamatához, de a módszereket fel lehet használni a környezeti állapot becslésére is (lásd pl. Lomborg [2001] számításait a Kyoto protocol várható hatásának és ráfordítás arányának tekintetében). Az ökológiai hatásvizsgálat az ökoszisztéma egyes komponenseit használja indikátornak, míg az élőhely értékelés (habitat evaluation) egy-egy ökoszisztéma fajnak történő megfelelését vizsgálja, vagy a fejlesztések hatását egy bizonyos élöhelyre vonatkoztatva (Barrow 1997).

Míg az imént említett vizsgálatok a fejlesztések bizonyos szegmenseire koncentrálnak, addig a területi tervezés, a területfejlesztés és az azokhoz kapcsolódó környezeti értékelések általában tágabb, ugyanakkor általánosabb döntés-előkészítést tesznek lehetővé. Különösen igaz ez a stratégiai környezeti vizsgálatra a környezeti hatásvizsgálathoz képest, ahol az egyeditől (környezeti hatásvizsgálat) az általános felé (stratégiai környezeti vizsgálat) mozdulunk el.

A fent említett analizisek tehát valamilyen állapotot vizsgálnak, azonban nem tartoznak a jelen cikk által tárgyalt környezeti értékelés, nevezetesen a stratégiai környezeti vizsgálat tárgykörébe, hiszen azok nem integrálódnak a tervezésdöntéshozás folyamatába választ adva a környezeti kérdések lehetséges jövőbeni állapotára, ezek elsősorban hatás jellegú elemzések. Természetesen vannak olyan SKV tanulmányok, amelyek politikákra, programokra vagy tervekre vonatkoznak, de ha azok nincsenek hatással a döntéshozás folyamatára, úgy nem tekinthetök ideális környezeti vizsgálatoknak. Thérivel és Partidário $(1999,4)$ felhívják arra is a figyelmet a stratégiai környezeti vizsgálat fogalmának meghatározásakor, hogy a különböző integrált menedzsment tervek, - amelyek egy-egy specifikus biotop környezeti hatásait vizsgálják (pl. part menti élöhelyek), - ha nincsenek közvetlen hatással a döntés- 
Varjú Viktor : A területi tervezés legújabb környezetértékelési metódusa - A stratégiai környezeti vizsgálat integrációja a döntéshozásba. - Tér és Társadalom 23. évf. 2009/1. 55-65. p.

TÉT XXIII. évf. 2009 - 1

A területi tervezés ...

hozásra, nem eredményeznek alternatív tervet vagy fejlesztést, szintén nem tekinthetők stratégiai környezeti vizsgálatnak.

A stratégiai környezeti vizsgálat, mint környezetpolitika tehát azt a célt szolgálja, hogy a területi tervezés, a területfejlesztés során olyan tervek, programok, fejlesztési elképzelések szülessenek, amelyek már magukban foglalják mindazokat a környezetvédelmi kritériumokat, amelyekkel a terv megvalósulása a lehető legkisebb környezeti kockázattal jár.

A stratégiai környezeti vizsgálat jelentősége abban rejlik, hogy optimális esetben már az átfogó fejlesztési terv során kiszüri azokat a környezeti rizikófaktorokat, amelyek a majd megvalósuló beruházások esetén csak a környezeti hatásvizsgálat során kerülnének felszínre. Így elkerülhetők az olyan szituációk, amikor - sarkítva fogalmazva - a munkagépet vissza kell hívni a munkaterületről a beruházás megkezdése elött, mert csak akkor derül ki, hogy bizonyos környezetvédelmi kérdések miatt a beruházás nem vagy nem abban a formában valósítható meg, ahogy az a tervekben szerepel.

A másik oldalról a stratégiai környezeti vizsgálat olyan területeken is érvényesítheti a környezetvédelmi érdekeket, ahol a környezeti hatásvizsgálatnak nincs szerepe. Így például az olyan kis volumenü beruházásoknál, ahol a jogszabály nem írja elő a hatásvizsgálat készítését. Az Európai Unió alapjainak felhasználásakor azonban számos ilyen lehetőség kínálkozik. A kisvállalkozások fejlesztéseinek kivitelezésekor ('igy például egy varroda több milliós nagyságrendủ szabászgépének cseréjekor) a (horizontális, mint például esélyegyenlőségi vagy környezetvédelmi) elöirások minimálisak, azonban a számtalan megvalósult fejlesztés összvolumene könnyen nagyobb környezeti hatást is kifejthet, mint egy-egy önálló nagyberuházás. Így például, mivel ezekre a kisvolumenü fejlesztésekre nem vonatkozik környezeti hatásvizsgálat, nem ellenőrzi gyakorlatilag senki, hogy a fejlesztéskor keletkező hulladéknak mi lesz a sorsa. A stratégiai környezeti vizsgálat azonban gazdaságfejlesztési terv szintjén előírhatja a különböző környezetvédelmi indikátoroknak való megfelelést. Vagyis csak azon szereplök pályázhatnak az egyes forrásokra, akik a pályázati anyagukban a környezeti terhelések kezelését is részletesen bemutatják.

Ahhoz azonban, hogy az SKV valóban elérje hatását nem mindegy, hogyan készül, a készítés folyamata hogyan integrálódik a tervezés és a döntéshozás folyamatába.

Ahogy a közösségi tervezéseknek, úgy mind a környezeti, mind a területi tervezésnek van egy bürokratikus és egy politikai gyakorlata. A bürokratikus rendszer az adott ország intézményi sajátosságaitól, struktúrájától, míg a szakmapolitikai gyakorlat az ország politikai hagyományaitól, annak gyakorlati megnyilvánulásaitól függ. A tervezés sikeréhez, az elképzelések megvalósításához azonban adaptálni kell mindkét gyakorlat karakterisztikáját. Természetesen ez meglehetősen nehéz feladat, mindazonáltal az integrált tervezésnek alkalmaznia és számolnia kell mindkettővel. Ez azonban hátráltathatja is a hatékony területi tervezést (PartidárioVoogd 2004). Jelen kérdésnek a stratégiai környezeti vizsgálatoknál külön jelentősége van. Ugyan a jogszabályi keretek meghatározzák, hogy az SKV-nak a tervvel 
Varjú Viktor : A területi tervezés legújabb környezetértékelési metódusa - A stratégiai környezeti

vizsgálat integrációja a döntéshozásba. - Tér és Társadalom 23. évf. 2009/1. 55-65. p.

együtt kell készülnie, de ez nyilvánvalóan a konzultációk iteratív jellegére, nem pedig a párhuzamosságra vonatkozik.

A nemzetközi - és a még nagyon fiatal - hazai szakirodalomban mind a mai napig vita van arról, hogy a környezeti vizsgálatnak hogyan kellene illeszkednie a tervezés, a fejlesztés folyamatába.

Az SKV alkalmazása során két általános szemlélet alakult ki. A hatásirányultságú SKV a KHV-k módszertanán alapul, figyelmük középpontjában a várható hatások minél precízebb meghatározása áll. A döntés-irányultságú SKV középpontjában a tervezési és a programozási döntéshozatali folyamatokhoz történő kapcsolódás, illetve a környezeti szempontok minél erösebb integrációjának elérése a cél (Szilvácsku 2003). Ez utóbbi megközelítést tartja szerencsésebbnek mind Ferencsik (2004), mind pedig Fleischer et al (2004), akik egymás mellett, külön kezelik az SKV-t és a KHV-t. Tehát az SKV nem a hatásokat vizsgálja, hanem a stratégiát helyezi a középpontba. Péti (2005) a két SKV típust szemléleti és módszertani szempontból közelíti meg. A hatás-irányultságú értékelést technocentrista felfogású értékelésnek nevezi, amely magában hordozza a projekt szintủ hatásvizsgálat tulajdonságait. Az ökocentrikus irányzat figyelemre méltó elemének tartja az úgynevezett analitikus SKV megközelítést, amely a tervezés környezetileg releváns, ún. döntési ablakainak azonosítására fókuszál.

A fogalmi meghatározások tekintetében is tapasztalható egyfajta bizonytalanság, nevezetesen, hogy a szakértők mit értenek terv, illetve program (stratégia), vagyis az SKV tárgya alatt. A hazai szakirodalom elsősorban a komplex, stratégiai jellegủ dokumentumokat tartja kívánatosnak SKV elemzés alá venni. Így a közlekedési fejlesztéseknél nem az útberuházásokra, hanem elsósorban a komplex stratégiára kívánják helyezni a hangsúlyt (Fleischer et al 2004), míg - ahogy Ferencsik (2004) is jelzi - bár tervnek nevezhetó egy hulladékgazdálkodási vagy vízhasználati terv is, a terv vagy program alatt - SKV vonatkozásában - projektek sorozatát célszerü érteni.

Mind a mai napig vita van arról is, hogy a stratégiai környezeti vizsgálatnak valójában mennyire kellene integráltnak lennie. Néhány szerző azt mondja, hogy a környezeti értékelést a tervezés-döntés-előkészítés-döntéshozás mechanizmusába kellene integrálni, míg mások amellett érvelnek, hogy a környezeti értékelésnek el kell különülnie ettől a folyamattól (Partidário-Voogd 2004).

Partidário és Voogd (2004) négyféle integrációs formát különböztet meg a környezeti vizsgálattal és a tervezési-döntési folyamatával kapcsolatban:

- Az elsö a „teljes integráció”, amikor is a környezeti faktorok és vonatkozások szerves részét képezik a stratégiai döntésnek, annak létrejöttében aktív szerepet játszanak.

- A „környezeti keret integrációban” a környezeti faktorok és vonatkozások ugyan formailag megvannak, szempontrendszerként jelen vannak, de értékelés nem történik a tekintetben, hogy a program megvalósítása mekkora és milyen irányú vélhető hatással lesz a környezetre.

- Az ,egyidejú értékelés”-kor a környezeti faktorok és vonatkozások számbavétele, a környezeti értékelés szimultán történik a szakpolitika kialakitásával. 
Varjú Viktor : A területi tervezés legújabb környezetértékelési metódusa - A stratégiai környezeti vizsgálat integrációja a döntéshozásba. - Tér és Társadalom 23. évf. 2009/1. 55-65. p.

TÉT XXIII. évf. 2009 a 1

A területi tervezés ...

- A „kapcsolt integrációnál” a környezeti értékelés csak azt követően történik, miután a terv már elkészültt, így az csak csatolmányként kerül a végső anyaghoz.

A szerzök szerint - és véleményünk szerint is - az első modell a kívánatos állapot, ahol a környezeti értékelés a tervezési folyamat során valóban aktív, iteratív módon hat a tervre, annak végkimenetelére, így maga a terv már olyan formában kerül a végső döntést meghozók elé, amely számol a környezeti érdekekkel (ha az értékelök jól végezték a munkájukat).

\section{Az SKV konceptuális kerete}

A stratégiai környezeti vizsgálatnak, hogy elérje célját és valóban ideálisnak lehessen tekinteni, az alábbiakban leírt elméleti keretbe kell(ene) illeszkednie.

A politika-terv-program-projekt szisztémában tehát az első háromra vonatkozik a stratégiai környezeti vizsgálat (SKV), mint környezeti előrejelzési módszer, míg a negyedikre a környezeti hatásvizsgálat (KHV). A politika-terv-program egyfajta hierarchiát is kifejez, azonban ezek definiálása nem ellentmondásmentes. Wood és Djeddour (1991) az alábbiak szerint javasolja tisztázni a fogalmakat: A politika egy inspirációja és útmutatása egy akciónak, a terv egy koordinált és időben behatárolt megnyilvánulása egy politika kezdeményezésének, míg a program projektek sorozatának a kifejeződése egy meghatározott területen (Wood-Djeddour 1991, 3).

Általában elmondható, hogy négy érdekcsoportot, aktort lehet megkülönböztetni a stratégiai környezeti vizsgálattal kapcsolatban. A tervezőt, aki a fejlesztési dokumentum elkészültéért felelős. Lehet ez egy fejlesztési ügynökség vagy egy magán vállalat, amely a tervet késziti valakinek a megbízásából. A kompetens hatóságot (általában a kormány vagy kvázi kormányzati szerv), amely a tervek, programok, politikák végrehajtásáért, a döntések meghozataláért felelös. A kompetens hatóság, valamint a tervező lehet egy és ugyanaz. Ilyen például az Egyesült Királyságban a Közlekedési Minisztérium, aki indítványozza az útfejlesztést, elkészíti a környezeti vizsgálatot, valamint dönt arról, hogy a program mehet-e tovább. (Az egyébiránt egy meglehetősen szerencsétlen szisztéma, amikor a tervezö végzi a környezeti vizsgálatot is.) A harmadik szereplő a környezetvédelmi hatóság(ok), amely konzultál és információkat biztosít a környezeti vizsgálat lefolytatásához. A negyedik csoport pedig maga az érintett közösség, amely a társadalmi vita során kap lehetőséget a terv esetleges módosítására (Wood-Djeddour 1991). (A magyar gyakorlat - legalábbis az operatív programok esetében - a környezeti vizsgálat tekintetében is külön társadalmi vitát biztosít, még az SKV tematikája tekintetében is.)

A tervezési folyamat a gyakorlatban azonban nem ilyen sarkos, hiszen az a már korábban említett bürokratikus és politikai intézményrendszerbe integrálódik, egy időben és térben meghatározott hatalmi struktúra része. İgy a normák és szabályok, valamint azok permanens változása a résztvevők szerepeinek cserélődéséhez, átfedéséhez vezethet, ezáltal a tervezési „stílusok” közötti határ is gyakran elmosódik. 
Varjú Viktor : A területi tervezés legújabb környezetértékelési metódusa - A stratégiai környezeti

vizsgálat integrációja a döntéshozásba. - Tér és Társadalom 23. évf. 2009/1. 55-65. p.

62

Varjú Viktor

TÉT XXIII. évf. 2009

Ebben a rendszerben tehát a környezeti vizsgálat illeszkedésére a „tervezési stílus” is hatással van (Faragó 2005).

Természetesen a stratégiai környezeti vizsgálatnak is megvannak a maga korlátai mind procedurálisan, mind pedig technikailag. Ezt bizonyítja az is, hogy a különböző országokban gyakran eltérő gyakorlatok alakultak ki az SKV-val kapcsolatban. Egyrészt, habár számos esettanulmány és kézikönyv is megjelent már a témában, máig nincs egységes, kialakult metódus az SKV-k készítésére vonatkozólag. A másik oldalról számos adat és információ is nehézkesen áll rendelkezésre, jobbára a tervböl kifolyólag, hiszen egy átfogó politikai elképzelésnek általában nincsenek meg a konkrét területi megnyilvánulásai, így az SKV-nak a területi dimenziója gyakran hiányos (ami nem jelenti azt, hogy a környezeti vizsgálat nem tölti be a szerepét). Folyamat oldalról maga a tervezés is gyakran homályos, érdekvezérelt, nem-lineáris és meglehetősen komplex, így gyakran a környezeti vizsgálat nem akkor készủl, amikor az valóban a terv végső formájára is hathatna és ténylegesen befolyásolhatná a döntéshozást (Thérivel-Partidário 1999).

A fentieknek megfelelően az egyes országok gyakorlata is eltéró az SKV megvalósításának vonatkozásában. Így például az Egyesült Államokban a környezeti vizsgálat meglehetósen széles körú és terjedelmes, és a társadalmi konzultációt hangsúlyozza; a holland gyakorlat erósen kapcsolódik a döntéshozási hierarchiához; a német SKV a mennyiségi értékelésre, valamint a földrajzi információs rendszerre (GIS) helyezi a hangsúlyt; a brit környezeti vizsgálat pedig inkább kvalitatív és viszonylag kis terjedelmú. Ezek a különbségek azonban számos egyéb más faktornak köszönhetőek, nem pedig az SKV modelljéböl és szabályozásából fakadnak (Thérivel-Partidário 1999).

\section{Az elsö magyar tapasztalatok}

Annak ellenére, hogy Magyarországon voltak már elözményei a stratégiai környezeti vizsgálatnak, az elmúlt években zajló tervezési folyamat nem mentes az ellentmondásoktól. Az Új Magyarország Fejlesztési Terv, a hozzá kapcsolódó ágazati és regionális operatív programok stratégiai környezeti vizsgálata elkészült. Ahogy a társadalmi vitákból látszott, a vizsgálat módszertana kevésbé, viszont maga a folyamat és annak elhúzódása meglehetősen ellentmondásos megítélésú ${ }^{1}$. Az eddigi tapasztalatok arra mutatnak rá, hogy a környezeti szempontok érvényesítése a tervezési folyamatban nem pusztán a jogi szabályozáson, a tervezési módszertanon, hanem a döntési mechanizmuson, a szereplökön és a szereplök tudásán is múlik. A fenti folyamatok kutatását és elemzését a G-FORS ${ }^{2}$ elnevezésü kutatás során végeztük, így az elözetes eredmények alapján számos megfontolás megfogalmazható.

Ahogy a kutatás eddigi eredményei mutatják, az átfogó területfejlesztési programokban a törekvések a döntés-irányultságú környezeti vizsgálat irányába mozdulnak el. A környezeti vizsgálatot végzők, valamint a tervezők elsődleges célja az 
Varjú Viktor : A területi tervezés legújabb környezetértékelési metódusa - A stratégiai környezeti vizsgálat integrációja a döntéshozásba. - Tér és Társadalom 23. évf. 2009/1. 55-65. p.

TÉT XXIII. évf. 2009 @ 1

A területi tervezés...

63

volt, hogy maga a stratégia tartalmazza a környezeti érdekeket, ne pedig azok hatásának értékelése és a visszacsatolás történjen meg. Ennek egyik legföbb oka éppen a tervek átfogó jellege volt. Ezek a fejlesztési programok ugyanis még jellemzően nem konkrét beruházásokat tartalmaznak, így azok konkrét hatását is nehéz megbecsülni. A cél tehát inkább az, hogy az átfogó területfejlesztési tervek során olyan környezeti vizsgálat történjen, amely az ilyen típusú átfogó fejlesztési programok jellegét befolyásolja környezetvédelmi szempontból.

Ha folyamatoldalról vizsgáljuk az eddigi országos szintủ tapasztalatokat, akkor azt mondhatjuk, hogy a kép nem ennyire pozitív. Kétségtelen, hogy a jelenlegi tervezési periódus (2007-2013) volt az első, ahol nagy volumenben történtek környezeti vizsgálatok. Így a részbeni tapasztalatlanságnak is betudhatóak a felmerülö ellentmondások, azonban a kutatás azt is mutatja, hogy ebben szerepe van a magyar túlzott bürokratikus intézményi rendszernek, valamint annak is, hogy a szakpolitikai elképzelések és a tervezés ugyan párhuzamosan, de gyakran különállóan, nem integrált módon történik.

A kutatás előzetes eredményeiből leszürhető, hogy elsősorban a bürokratikus nehézségek miatt néhány környezeti vizsgálat készítése során csak (a Partidário-Voogd [2004] elmélet szerinti) „,kapcsolt integráció” valósult meg. Ugyanis előfordult az, hogy a fejlesztési terv készítése már lezárult, azonban a környezeti értékelés még ,javában zajlott" (erre utalnak az interjúalanyokon kívül a tervezési dokumentumok dátumai is). Mivel ekkor már nincs lehetőség arra, hogy a környezeti vizsgálatban megfogalmazottak érvényesüljenek a tervben, az SKV csak egy, a jogszabályi kritériumoknak ugyan megfelelö, kötelezö csatolmánya a területfejlesztési tervnek.

Egy másik kutatásban megpróbáltuk feltárni azt, hogy helyi szinten a törvény hatályba lépése óta milyen tapasztalatok szürhetök le a környezeti vizsgálat alkalmazásában a helyi területfejlesztési törekvésekkel kapcsolatban. Bár a kutatás még zajlik, az elsö eredmények azt sugallják, hogy a probléma teljesen más megközelítést igényel. Egyrészt eddigi kutatásunkból az látszik, hogy a helyi önkormányzatok 2005. január 1-jét követő településfejlesztési elképzeléseik (településrendezési terv, településfejlesztési koncepció stb.) során jellemzően nem alkalmazták a környezeti vizsgálatot. Ez fóként azért történhetett, mert nem volt ismert számukra az, hogy környezeti értékelést kell végezni ezekre a tervekre, valamint - részben - azok az önkormányzatok véleménye szerint a környezetre nincsenek olyan nagy hatással. Mindazonáltal, ha a jövöben végeznének is ilyen környezeti értékelést, annak hasznosságát kevésbé látják meggyőzőnek, mint inkább azt a tényt, hogy az adott önkormányzatra ez az értékelés újabb anyagi terhet ró.

Itt jegyzendö meg azonban, hogy sem a magyar jogszabály, különösen igaz pedig ez az uniós irányelvre, nem szabályozza le azt, hogy pontosan milyen mértékú fejlesztésekhez szükséges SKV-t végezni. Így a magyar jogszabály nem kötelezi a kidolgozókat a település egy részére készülő szabályozási tervnél SKV készítésére, illetve - bár magyar keretek között jóval szủkebben, mint az uniós irányelvnél némi mozgásteret is ad a kidolgozónak a tekintetben, hogy meghatározza azt, hogy az adott tervnek mekkora a várható környezeti hatása. Erre a „szabad mozgástérre” 
Varjú Viktor : A területi tervezés legújabb környezetértékelési metódusa - A stratégiai környezeti vizsgálat integrációja a döntéshozásba. - Tér és Társadalom 23. évf. 2009/1. 55-65. p.

hivatkozva azonban az önkormányzatoknak lehetőségük lehet arra, hogy kisebb módosításoknál elkerüljék a környezeti vizsgálat kötelezettségét (hivatkozva arra az egyébként jogos, de ahogy a fentiekből kiderülhetett, nem releváns felvetésre, mely szerint a környezethasználatot jelentő tevékenységek vagy létesítmények úgyis hatósági engedélyezési kötelezettséggel bírnak).

\section{Összegzés}

A hogy a szakirodalom is megfogalmazza: „A területfejlesztés komplex tevékenység, melynek fö feladata az elmaradott térségek kialakulásának megelőzése, a fejletlenebb térségek fejlödési potenciáljának kisugároztatása. Célja a helyi és térségi, társadalmi partnerségen alapuló gazdaságfejlesztési folyamatok beindítása, támogatása." (László-Magay 2005, 56) Ahhoz azonban, hogy a területfejlesztés valóban elérje fenti célját, arra is szükség van, hogy a komplexitásba beletartozzon a stratégiai környezeti vizsgálat, amely nem kötelezö csatolmánya kell, hogy legyen a tervdokumentumoknak, hanem a tervezés során kellene érvényesülnie. A területfejlesztési szakembereknek, valamint a kidolgozóknak és a tervezőknek tehát arra kell törekedniük, hogy a környezeti vizsgálat a tervezési folyamat része legyen, és a célok meghatározásakor a tervdokumentumba csak olyan fejlesztések kerüljenek, amelyek a környezetvédelmi érdekekkel összhangban állnak.

Bár a stratégiai környezeti vizsgálatban jellegénél fogva sokszor nehezen fogható meg a térszemlélet - (elsősorban az átfogó fejlesztési elképzeléseknél) mivel a tervek, programok, koncepciók regionális, területi lehatárolása (a beruházások pontos helyszinének kijelölése) a tervezés ezen fázisában nehezen meghatározható, vagy csak valószínüsíthetö -, ennek ellenére fontos, hogy a szakértők hangsúlyt helyezzenek a területi szemlélet érvényesítésére is, legalább a tekintetben, hogy a valószínüsíthető helyszíneken, vagy regionális tervekben számbavételre kerüljenek a helyi, területi sajátosságok, vagy legalább elvi szinten ki lehessen dolgozni a negatív hatások elkerülésének, a pozitívak fokozásának módjait.

\section{Jegyzetek}

\footnotetext{
${ }^{1}$ A vitát lásd: https://www.smartportal.hu/respect/index.php [cit. 2007.12.01]

${ }^{2}$ Governance for Sustainability (G-FORS) nemzetközi projekt - EU 6. Keretprogram 7. prioritás. A magyar partner kutatásvezetöje Prof. Pálné Dr. Kovács Ilona DSc., az MTA RKK DTI igazgatója. www.g-fors.eu
} 
Varjú Viktor : A területi tervezés legújabb környezetértékelési metódusa - A stratégiai környezeti

vizsgálat integrációja a döntéshozásba. - Tér és Társadalom 23. évf. 2009/1. 55-65. p.

TÉT XXIII. évf. 2009 a 1

A területi tervezés ...

65

\section{Irodalom}

2/2005. (I. 11.) Kormányrendelet egyes tervek, illetve programok környezeti vizsgálatáról. Budapest.

Barrow, C.J. (1997) Environmental and Social Impact Assessment. Arnold, London.

DIRECTIVE 2001/42/EC OF THE EUROPEAN PARLAMENT AND OF THE COUNCIL of 27 June

2001 on the assessment of the effects of certain plans and programmes on the environment. Brussels.

Faragó L. (2005) A jövőalkotás társadalomtechnikája. Dialóg Campus Kiadó, Pécs-Budapest.

Fleischer T.-Magyar E.-Tombácz E.-Zsikla Gy. (2004) Gondolatok a közlekedés-fejlesztési programok stratégiai kömyezeti vizsgálatáról. - ÖKO. 1-2.56-66. o.

Ferencsik I. (2004) Stratégiai Kömyezeti Vizsgálat (SKV) - az alapok, - Falu-Város-Régió. 6. 5 I-55. o.

László M.-Magay M. (2005) A terület- és településfejlesztés szervezeti és intézményi renđszere. - Pap N.-

Tóth J. (szerk.) Terillet- és Településfejlesztés I. Alexandra Kiadó, Pécs. 27-68. o.

Lomborg, B. (2001) The Skeptical Environmentalist. Cambridge University Press, Cambridge.

Pálné Kovács I. (2005) Közigazgatási reformok, uniós tagság, regionalizmus. - Pálné Kovács I. (szerk.) Regionális reformok Európában. Timp Kft., Budapest. 9-42. o.

Partidário, M.-Voogd, H. (2004) An Endeavour at Integration in Environmental Analysis and Planning.

- Miller, M.-De Roo, G. (eds.) Integrating City Planning and Environmental Improvement.

Practicable Strategies for Sustainable Urban Development. Ashgate, Aldershot. 285-294. o.

Péti M. (2005) A stratégiai környezeti vizsgálat a fenntartható (területi) tervezés szolgálatában. - FaluVáros-Régió. 3-4. 43-56. o.

Szilvácsku Zs. (2003) Stratégiai környezeti vizsgálatok gyakorlata az Európai Unióban. Vitaregnat Bt., Budapest.

Szirmai V. (1999) A környezeti érdekek Magyarországon. Pallas Stúdió, Budapest.

Thérivel, R.-Partidário, M. (1999) The Practice of Strategic Environmental Assessment. Earthscan, London.

Tombácz E.-Magyar E.-Mozsgai K. (2003) Stratégiai Környezeti Vizsgálat. Egy lehetséges módszertan a Regionális Operativ Program környezeti szempontú ex-ante értékelésének megalapozásához. http://www.rec.hu/skv/doc/SKV jelentes.pdf (Letöltve: 2007.10.31.)

Wood, C.--Djeddour, M. (1991) Strategic Environmental Assessment: EA of Policies, Plans and Programmes. - The Impact Assessment Bulletin. 1. 3-22. o.

\section{THE LATEST ENVIRONMENTAL ASSESSMENT METHOD IN LAND-USE PLANNING - STRATEGIC ENVIRONMENTAL ASSESSMENT (SEA) INTEGRATION IN DECISION-MAKING}

\section{VIKTOR VARJÚ}

The idea of "sustainable development" becoming widespread has resulted in the desira bility of using previous environmental evaluation of investments and as well as plans. Since the redistribution (subsidies) system of the EU Structural Funds resulted in greater and greater projects and plans, the role of evaluation has increased. For the safekeeping of the natural environment, the European Community introduced the Environmental Impact Assessment $(85 / 337 / \mathrm{EC})$. This assessment "only" concerned to concrete building projects in order to reveal the dangers of investments to the nature. Later on, extending the Assessment and using the practice of some developed countries, the EU introduced the Strategic Environmental Assessment (SEA) in its Directive 2001/42/EC.

The SEA is not just an environmental methodology but should be an integrated, iterative element of the planning and decision-making process in order to achieve the aim of sustainable development. The article presents the different types of integrating levels and the modes of environmental evaluation on the conceptualisation based. Some basic statements and experience can also available in this paper, showing the latest problems and questions of the introduction of SEA in Hungary. 